\title{
Obituary
}

\section{Alan James Gardner, Consultant Psychiatrist, German Hospital, London $\mathrm{E8}$.}

Alan Gardner was a good friend, a wise physician, a truly gentle man. Like many of such a kind, he did what he had to do without fuss, with little public show, no flashy ostentation, self-effacingly, patiently, persistently. He was that rarity-a man who set his own high standards and dedicated his life to attaining them.

He was born on 20 January 1936. He entered the Royal Free Medical School in 1952 and qualified in 1958. He spent the next seven years acquiring a rounded training, in medicine, radiology, neurology and paediatrics. Only then did he enter psychiatry, training at West Park, Guys, the Bethlem Royal and Maudsley Hospitals and The London before his appointment as the first psychogeriatrician to Barts' in 1974. In recommending him, the late Sir Desmond Pond remarked on his "extensive experience in general medicine", an experience we his colleagues and a decade of students and trainees were often to call upon with advantage and relief. Sir Desmond also commented of Alan that he was "certainly not one of those trainees who constantly complain that their clinical load prevents them doing any research"-an astute comment on Alan's conscientiousness and application and his thirst for hard work, then in research, in which he showed great flair, later in clinical psychiatry and in the planning and development of services. His consultant at The London, then Dr now Professor Sam Cohen, noted of his curriculum vitae "the thoroughness with which this is composed reflects a quality which is apparent in all the work that he did here".

Experienced, uncomplaining, thorough-these were the qualities of the man and they were to fuel and carry him through the 13 years that he spent building up the psychogeriatric services of the City and Hackney, the psychiatric teaching at the medical school and the clinical skills of us all. I must confess that I myself did not realise the extent to which Alan Gardner was the psychogeriatric service. The year he arrived-1974-he initiated the Consultant Domiciliary Service for the elderly. Now such an approach is commonplace. Then it was quite new. When he arrived, there were 36 beds at the German Hospital and a few outpatient clinics. That was the psychogeriatric service. The mentally ill elderly were expected to lift up their beds and walk or be brought to the hospital services. For Alan, the responsibility became that of bringing the hospital-based services to their homes.

And so it was that the first home-based psychiatric service for the elderly in London was born, and some years before the current vogue for community - and it was born without fuss, without trumpets, without a plethora of committees, without wider public recognition. It was to be the first of a whole series of developments. In 1976, the first 14-bedded psychogeriatric assessment unit was opened at the German Hospital and the same year saw set up a 30 place Day Hospital capable of supporting 50-60 elderly patients in the community. In 1977 he inaugurated a Relative Support Group and the next year he pushed forward the first 20bedded high dependency ward for the elderly mentally ill in the District. 1979 saw the inauguration of the community psychiatric nursing service for the elderly and in 1982 the second 20-bedded high dependency unit was opened as was a hospital based night shelter.

Alan Gardner did all this and more while undertaking an extensive commitment to general adult psychiatry as well. It was not until 1985 that his burden was to be eased a little with the arrival of his friend and colleague, Brice Pitt, but Alan remained at the heart of what was now a rapidly expanding responsibility vis-à-vis planning-new community nursing home facilities on the sites of the Mother's and the German Hospitals, the closure of the German and the transfer of beds to St John's all in preparation for the purpose-built psychiatric and psychogeriatric facilities in phase 2 of the Homerton Hospital, for which he longed and which he will now sadly never see.

But he will be remembered-in the hearts and minds of those he worked with and alongside, and of those he cared for, the elderly mentally ill and their relatives. And he will be remembered objectively and celebrated too in the decision to name one of the wards in the new psychiatric facilities in Homerton Hospital after him, after the man who more than anyone else originated and developed the services for the elderly mentally ill in this part of London.

It is small recognition of his struggle to provide a highstandard service with limited resources-those consultants in medicine and in surgery who are understandably stressed and preoccupied by the dreadful and draining task of having to turn away or delay the admission of acutely sick people might spare a thought for the fact that the lot of many a psychogeriatrician in London at the present time, and certainly of Alan Gardner since 1974, is somehow to struggle to maintain in an often hostile and socially fragmented community some exceedingly frail and incapacitated men and women-and Alan lived with such decisions every day of his working life.

His wife and his children knew and know better than any of us the strength of his commitment. To them all his colleagues express gratitude that he gave us so much and some regret that we took sometimes thoughtlessly. For as long as psychogeriatric medicine is practised he shall be remembered. 